УДК 372.881 .1

I. А. Дирда

\title{
КОМУНІКАТИВНИЙ ПІДХІД ДО НАВЧАННЯ УКРАЇНСЬКОЇ МОВИ ЯК ІНОЗЕМНОЇ НА ОСНОВНОМУ ЕТАПІ
}

Дирда I. А. Комунікативний підхід до навчання української мови як іноземної на основному етапі.

У статті проаналізовано погляди науковців щодо визначення поняття «підхід». Основну увагу зосереджено на комунікативному підході, визначено його сутність та переваги на основному етапі вивчення української мови як іноземної.

Ключові слова: підхід, комунікативний підхід, українська мова як іноземна, основний етап вивчення української мови.

Дырда И. А. Коммуникативный поход в изучении украинского языка как иностранного на основном этапе.

В статье были проанализированы взгляды учёных относительно определения понятия «подход». Основной акцент был сделан на коммуникативный подход, его содержание и преимущества на основном этапе изучения украинского языка как иностранного.

Ключевые слова: подход, коммуникативный подход, украинский язык как иностранный, основной этап изучения украинского языка.

Dyrda I. A. The communicative approach to studying Ukrainian as a foreign language in the main stage.

The paper deals with the analysis of scientists' views concerning the term «approach». The communicative approach, its intention and advantages in the main stage of studying Ukrainian as a foreign language are accentuated.

Key words: approach, communicative approach, Ukrainian as a foreign language, the main stage of studying Ukrainian.

Специфіка методики викладання української мови як іноземної полягає в тому, що сам предмет навчання стає засобом засвоєння фахових предметів, пізнання нового середовища, нової культури, нових традицій. Вивчення мови $є$ засобом отримання професійної освіти та розвитку особистості, що може вести діалог культур.

Особливість сучасного стану у викладанні іноземної мови полягає у докорінній зміні методичної та методологічної парадигми мовної освіти. «Концепція мовної підготовки іноземців у ВНЗ України» $\epsilon$ невід'ємним складником державної Концепції мовної освіти та грунтується на основних положеннях Конституції України, законах України «Про освіту», Державній національній програмі «Освіта: Україна XXI століття», Свропейській хартії регіональних мов або мов меншин, 
Загальноєвропейських Рекомендаціях з мовної освіти.

Важливим чинником у засвоєнні мовної системи є визначення підходів. Лінгводидактами було запропоновано різноманітні підходи щодо вдосконалення процесів навчання мови (А. Алексюк, Н. Бабич, 3. Бакум, Л. Барановська, О. Біляєв, І. Бім, С. Вітвицька, М. Вятютнєв, І. Зимня, С. Караман, О. Копусь, С. Ніколаєва, Ю. Пассов, М. Пентилюк, В. Скалкін, Н. Ушакова, С. Яворська). У дослідженнях цих науковців визначено вдосконалення процесу навчання як такого управління, що організоване на основі всебічного врахування закономірностей, принципів навчання, сучасних методів i форм задля досягнення найефективнішого функціонування процесу навчання.

На думку російського лінгводидакта В. Скалкіна, підхід дослідницька діяльність, яка має теоретико-експериментальна основу та спрямована на аналіз більш складного явища чи процесу з якогось одного боку в межах певної групи чинників або умов, у контексті певної форми його існування. За визначенням дослідника, «підхід - це робочий етап у дослідженні. Як тільки воно завершиться, його функцію буде вичерпано» [5, с. 121-122]. І. Зимня характеризує «підхід» як: 1) світоглядну категорію, яка відображає соціальні настанови суб'єктів навчання як носіїв суспільної свідомості; 2) глобальну та системну організацію й самоорганізацію, до складу якої входять усі його компоненти [2].

На думку С. Омельчук, підхід - це «методологічна категорія лінгводидактики, що позначає складне багатовимірне явище, системну сукупність якого становлять принципи, технології, методи, прийоми, засоби й форми навчання, і яке характеризується концептуальністю, процесуальністю, системністю, керованістю й дієвістю» [4].

Г. Строганова вважає, що сучасні підходи до навчання української мови як іноземної повинні задовольняти такі вимоги: 1) формування мовних засад для оволодіння знаннями 3 української мови, для чого обов'язковим є врахування мовного досвіду та рідної мови слухача; 2) вибір певного варіанта мовної системи для навчання; 3) використання під час навчання всіх функцій мови задля вільного оволодіння чотирма видами діяльності (читанням, говорінням, слуханням, письмом) [5].

Отже, з позиції лінгводидактики, основу поняття «підхід» складає певна ідея або концепція, сукупність принципів, яка скеровує дослідження, організацію і процес навчання мови.

У програмах з української мови як іноземної визначено, що освітня та пізнавальна мета навчання реалізуються за умови набуття студентом достатнього рівня володіння українською мовою, тому комунікативний ().А. Дирда, 2015. $-434-$ 
підхід в навчанні української мови як іноземної є одним з основних. Аби реалізувати його, студент має набути необхідних мовних і мовленнєвих умінь для здійснення комунікації державною мовою країни, у якій навчається.

Українські лінгводидакти (3. Бакум, О. Біляєв, С. Караман, Л. Паламар, М. Пентилюк, К. Плиско) визначають навчання спілкування як навчання діяльності, яке характеризується дослідженням пізнавальної діяльності суб' єктів навчання, а також проблем формування системи знань тих, хто навчається. Студентам-іноземцям українська мова потрібна як засіб реального спілкування $з$ україномовними людьми під час навчання i професійної діяльності. Комунікативний підхід спрямований саме на практику спілкування. Однією 3 провідних особливостей комунікативного підходу $є$ ситуативність. Важливо правильно дібрати актуальні та корисні комунікативні ситуації для розвитку мовлення, що не тільки допоможе зацікавити студентів, а й створюватиме мотивацію навчання. Акти спілкування за участю одного чи кількох співрозмовників зазвичай здійснюються користувачами мови для задоволення їхніх потреб у цій ситуації [3, с. 95].

Ще одна особливість комунікативного підходу, яка відрізняє його від інших, полягає в тому, що студенти мають можливість самостійно вибирати мовні засоби для оформлення своїх думок і вираження себе як особистості. Особистість студента та його інтереси поставлені в центр навчального процесу, що відповідає основному критерію сучасної дидактики. Комунікативний підхід у навчанні української мови як іноземної на основному етапі передбачає максимальне заглиблення студента в україномовний процес. Здебільшого значення нових слів розкриваються на основному етапі вивчення мови шляхом пояснення значення нового слова за допомогою вже відомої лексики.

На наш погляд, комунікативний підхід до навчання є ефективним у межах формування навичок спілкування, оскільки на заняттях відбувається активізація мовленнєвомислительних резервів, які дозволяють передати зміст висловлювання. Комунікація залучає аспекти культури (показує розбіжності під час сприйняття та передачі інформації), спрямовує на практичне володіння українською мовою в різних видах діяльності, а упровадження методу ситуацій, близьких до дійсності, підвищує інтерес іноземних студентів до предмета.

Перевагами комунікативного підходу до навчання української мови як іноземної на основному етапі $є$ такі: у процесі навчання студенти розуміють висловлювання $з$ достатньо складним лексичним наповненням, 
розпізнають імпліцитне значення; вміють висловлюватись швидко і спонтанно без помітних утруднень, пов'язаних 3 пошуком засобів вираження; удосконалюють уміння ефективно і гнучко користуватись мовою у суспільному житті, навчанні та роботі. Зазначені переваги засвідчують, що комунікативний підхід до навчання української мови як іноземної на основному етапі $\epsilon$ ефективним, оскільки він спрямований на активний розвиток умінь студента спілкуватися українською мовою.

\section{Література}

1. Бакум 3. П. Українська мова як іноземна: Лінгводидактичні проблеми / 3. П. Бакум // Філологічні студії : Науковий вісник Криворізького державного педагогічного університету : зб. наук. праць. - Вип. 5 / [заг. ред. Ж. В. Колоїз]. Кривий Ріг : Видавничий дім, 2010. - С. 226-232.

2. Зимняя И. А. Педагогическая психология : [учебник для вузов] / И. А. Зимняя. - [2-е изд., доп., испр. и перераб]. - М. : «Логос», 1999. - 384 с.

3. Ніколаєнко В. В. Компетентнісний підхід до формування російськомовних комунікативних умінь іноземних студентів / В. В. Ніколаснко // Викладання мов у вищих навчальних закладах освіти на сучасному етапі. Міжпредметні зв'язки. Наукові дослідження. Досвід. Пошуки. - 2013. - № 22. - С. 178-184.

4. Омельчук С. А. Методика навчання морфології української мови в основній школі на засадах дослідницького підходу : дис. ... д-ра пед. наук / С. А. Омельчук. Херсон, 2014. - $537 \mathrm{c}$.

5. Скалкин В. Л. Основы обучения устной иноязычной речи / В. Л. Скалкин. М. : Рус. яз., 1981. -248 c.

6. Строганова Г. Концептуальні підходи до засвоєння української мови іноземними студентами / Г. Строганова // Теорія і практика викладання української мови як іноземної : зб. наук. праць. - 2008. - Вип. 3. - С. 173-179.

7. Ушакова Н. І. Концепція мовної підготовки іноземців у ВНЗ України / Н. І. Ушакова, В. В. Дубичинський, О.М.Тростинська // Викладання мов у вищих навчальних закладах освіти. Міжпредметні зв'язки : зб. наук. праць. - Х. : ХНУ ім. В. Н. Каразіна, 2011. - Вип. 19. - С. 136-146.

Стаття надійшла до редакиії 18.07.2015 p. 